\title{
Development of Magnesium Fertilizer Replacing Kieserite from Bio-Physico-Chemical Activated Dolomite
}

\author{
Didiek Hadjar Goenadi, Laksmita Prima Santi, Donny Nugroho Kalbuadi \\ Indonesian Research Institute for Biotechnology and Bioindustry, Bogor, Indonesia \\ Email: laksmita.santi@gmail.com
}

How to cite this paper: Goenadi, D.H., Santi, L.P. and Kalbuadi, D.N. (2022) Development of Magnesium Fertilizer Replacing Kieserite from Bio-Physico-Chemical Activated Dolomite. Journal of Minerals and Materials Characterization and Engineering, 10, 81-92.

https://doi.org/10.4236/jmmce.2022.101006

Received: December 30, 2021

Accepted: January 26, 2022

Published: January 29, 2022

Copyright $\odot 2022$ by author(s) and Scientific Research Publishing Inc. This work is licensed under the Creative Commons Attribution-NonCommercial International License (CC BY-NC 4.0). http://creativecommons.org/licenses/by-nc/4.0/

\section{Open Access}

\begin{abstract}
All plants, especially cocoa and oil palm, require magnesium $(\mathrm{Mg})$ along with other macro- and micro-nutrients. Kieserite as the most common Mg-supplying fertilizer for crops is still imported for Indonesia due to lack of natural deposits in the country. On the other hand, dolomites $\left(\mathrm{CaMgCO}_{3}\right)$ are found abundantly and mostly used as liming material due to low $\mathrm{MgO}$ content and solubility as well. Many efforts have been carried out since a century ago to convert dolomite into $\mathrm{Mg}$ fertilizer substituting kieserite. However, there are no efficient processes available yet and therefore it is the objective of this study to develop a potentially efficient process by employing bio-physico-chemical activation approach in converting dolomite into kieserite-like product. A series of experiments were conducted by using a calcinated dolomite from Sidayu, Gresik, East Java, reacting with $\mathrm{H}_{2} \mathrm{SO}_{4}$, and inoculating with Mg-solubilizing microbes. An 80-mesh calcined dolomite powder was reacted with water at 1:3 ratio $(\% \mathrm{w} / \mathrm{v})$ and after one hour stirring added with technical grade $\mathrm{H}_{2} \mathrm{SO}_{4}$ improving $27.7 \% \mathrm{MgO}$ content from $18 \%$ to $23 \%$. The formula was then tested its effectiveness for cocoa and oil palm seedlings in the greenhouse for three and six months, respectively. By combining NPK fertilizer at standard dosage with the formula of $\mathrm{Mg}$-fertilizer at $75 \%$ of kieserite rate yielded the highest performances by six-month-old oil palm seedlings in a greenhouse experiment. To obtain conclusive results under field conditions, the formula was tested at field experiments using immature and mature oil palm trees. At $0.9 \mathrm{~kg} /$ tree/year dosage, the $\mathrm{Mg}$-fertilizer formula was superior to conventional kieserite at $1.6 \mathrm{~kg} /$ tree/year rate in supporting vegetative growth of immature oil palm. From the mature oil palm trial, it can be concluded that the use of the new formulated Mg-fertilizer at 50\% rate of conventional kieserite $(2 \mathrm{~kg} /$ tree/year) resulted in an insignificant different yield of fresh fruit bunches (FFB) compared to standard kieserite dosage.
\end{abstract}




\section{Keywords}

Sidayu Dolomite, Calcination, Acidification, Mg-Solubilizing Microbe

\section{Introduction}

Kieserite $\left(\mathrm{MgSO}_{4}\right)$ is a well-known magnesium $(\mathrm{Mg})$ fertilizer in the world that originated from natural deposits especially in sub-tropical regions containing > $26 \% \mathrm{MgO}$ and $50 \% \mathrm{SO}_{3}$ [1]. In contrast, most of agricultural countries in tropical regions have no natural resources so that almost all $\mathrm{Mg}$ fertilizer supplied by Kieserite is highly dependent on imported products. As consequence, the price is considerably high since very limited, if any, domestic resources are readily available to substitute kieserite as $\mathrm{Mg}$-fertilizer for agricultural crops. There are some others Mg-bearing mineral present in tropical region, such as dolomite $\left(\mathrm{CaMgCO}_{3}\right)$, serpentine $\left(\mathrm{MgSiO}_{4}\right)$, and feldspars $\left(\mathrm{KCaMgSiO}_{4}\right)$ [2]. However, these minerals neither have high content nor high solubility of $\mathrm{Mg}$ compared to Kieserite. Therefore, there were many interests by researchers to develop an efficient process in conversion such minerals to be compatible with Kieserite as $\mathrm{Mg}$ fertilizer. Many researchers have reported the application of this fertilizer [3] [4], especially for oil palm [5] [6] [7] in which some of them were interested in finding the most effective mineral to substitute kieserite.

Dolomite is a calcium-magnesium carbonate $\left(\mathrm{CaMgCO}_{3}\right)$ mineral that has been thoroughly reviewed by [8] and found abundantly in sub- and tropical regions including China [8] [9] [10] [11], Hungary [12], United States of America [13], and Indonesia [14]. The use of dolomite for crop has also been widely known [15] [16]. However, due to its low content and solubility of Mg many efforts were carried out to find most efficient process in improving these characteristics so that the processed dolomite could be used to substitute kieserite. Many processes have been proposed mainly based on calcination and/or acidification [17] [18] [19]. However, all of these results were still failed to achieve a high $\mathrm{MgO}$ content. Therefore, it is time to develop other alternative for processing dolomite to be a kieserite substitute.

Nutrient solubility in soils to some extend is almost always facilitated by microbial activities, especially when dealing with the solubilization of hardly soluble nutrients from natural rock materials. Recent studies indicated the incorporation of silica-solubilizing microbe improved significantly soluble $\mathrm{Si}$ in a $\mathrm{Si}$ fertilizer formulation [20] [21] [22]. Such phenomenon was also reported earlier by [23] [24] for potassium from feldspar and phosphate from selected natural phosphate rocks, respectively. The current study reports the development of biophysico-chemical activation of a domestic dolomite to produce alternative $\mathrm{Mg}$ fertilizer for conventional kieserite. Considering the highly abundant dolomite deposits in Indonesia, this technology will enjoy profitable commercial application to diversify the more affordable Mg fertilizer, especially for oil palm smallholders. 


\section{Materials and Methods}

\subsection{Chemical Properties}

A 100-mesh dolomite originating from Sidayu, Gresik, East Java, Indonesia was used in this experiment as raw material for formula development. Prior to and after physical-chemical treatment it was subjected to selected chemical analyses. Selected chemical analyses performed were including $\mathrm{pH}$, calcium $(\mathrm{Ca})$, total and water-soluble magnesium $(\mathrm{Mg})$, aluminum $(\mathrm{Al})$-, iron $(\mathrm{Fe})$-, and silicon $(\mathrm{Si})$-oxides, neutralizing capacity, and water content determination by using standard laboratory analyses outlined by SNI 13-3494-1994 (ICS 73.080).

\subsection{Physico-Chemical-Biological Treatments}

The physical treatment was carried out by calcining a 100-mesh dolomite powder at $400^{\circ} \mathrm{C}$ in a muffle furnish for one hour [25] [26]. The calcination was continued at $800^{\circ} \mathrm{C}$ for another one hour. After cooling at room temperature, the calcinated dolomite was added with distilled water with 1:3 ratio $(\mathrm{w} / \mathrm{v})$ stirred for 30 minutes. Finally, a technical grade of sulfuric acid $\left(\mathrm{H}_{2} \mathrm{SO}_{4}\right)$ solution $(96 \%$ in purity, Shijiazhuang Xinlongwei Chemical Co., LTD) was added to dolomite milk suspension at $14 \%(\mathrm{v} / \mathrm{v})$ and stirred further for another 30 minutes. The treated sample was then dried oven at $110^{\circ} \mathrm{C}$ for overnight. Inoculation of the activated sample was performed by spraying a suspension containing $10^{9} \mathrm{cfu}$ of phosphate-magnesium-solubilizing Pseudomonas $s p$ at $5 \%(\mathrm{v} / \mathrm{w})$ rate. The isolate was obtained from the IRIBB Culture Collection and precultured on a Pikovskaya agar medium containing (per L medium): $5 \mathrm{~g} \mathrm{Ca}_{3} \mathrm{PO}_{4} \cdot 3 \mathrm{OH}, 0.2 \mathrm{~g} \mathrm{NaCl}$,

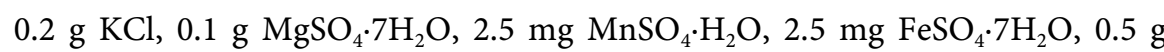
$\left(\mathrm{NH}_{4}\right)_{2} \mathrm{SO}_{4}, 10 \mathrm{~g}$ glucose, $0.5 \mathrm{~g}$ yeast extract, and $15 \mathrm{~g}$ bacto agar. The formulated kieserite (FK) was in the granular form with $3-5 \mathrm{~mm}$ diameter average after mixing with non-activated dolomite [25\%:75\% (w/w)] and adding $1 \%(\mathrm{w} / \mathrm{w})$ humic substance. The final formula of FK contained $28 \% \mathrm{MgO}$ (minimum).

\subsection{Mineralogical Characteristics}

An X-ray diffraction (XRD) analysis was performed using random-oriented samples analyzed by XRD using $\mathrm{Cu}$ Ka radiation at $40 \mathrm{kV}$ and $30.0 \mathrm{~mA}$ from XRD-6000 Shimadzu equipped with low divergence and receiving slits and a graphite monochromator on the $800^{\circ} \mathrm{C}$-one hour calcined and uncalcined dolomite samples to determine mineralogical composition by running at $0^{\circ}-30^{\circ}$ 2-theta with $\mathrm{Cu} \mathrm{Ka}$ at the Research Institute for Mineral and Coal (Tekmira) Bandung. Identification of the mineral present was carried out by using major intensive peak characterizing the mineral according to [27]. Differences in XRD patterns between the two sample will be used as supporting evidences for evaluating the effects of the physical treatment on the mineralogical characteristic.

\subsection{Experimental Designs}

A greenhouse experiment was conducted to evaluate the effectiveness of formu- 
lated dolomite as $\mathrm{Mg}$ fertilizer for oil palm seedlings in comparison with kieserite. Two-month old Dura $\mathrm{x}$ Psifera oil palm seedlings were grown for six months in a pot containing Ultisols soil media. The treatments applied were eight combinations of conventional NPK fertilizer and selected dosages of formulated kieserite (FK) in comparison to conventional kieserite and dolomite as follows: 1) NPK (A) + kieserite (B), 2) A + FK at 25\% B, 3) A + FK at 50\% B, 4) $\mathrm{A}+\mathrm{FK}$ at $75 \% \mathrm{~B}, 5) \mathrm{A}+\mathrm{FK}$ at $100 \% \mathrm{~B}, 6) \mathrm{A}+\mathrm{FK}$ at $125 \% \mathrm{~B}, 7) \mathrm{A}+\mathrm{FK}$ at $150 \%$ $\mathrm{B}$, and 8) $\mathrm{A}+$ dolomite. Arranged in complete random design the treatments were replicated three times. Parameters observed include leaf, roots, and stem dry weight and the data were subjected to analysis of variance and Duncan's Multiple Range Test $(\mathrm{p}<0.05)$ to determine the different effect among treatments. A field experiment was conducted both with immature and mature crops in Tinjowan Estate, North Sumatera, Indonesia, on an Ultisols soil. Using threeyear old immature and a five-year-old mature crops the experiments were set in randomized block design with three replicates and the plot size was two hectares for immature and five hectares for mature crops. The treatments for immature crops consisted of some combinations of NPK fertilizer with: 1) kieserite 1.6 kg/tree/year, 2) FK 0.6 kg/tree/year, 3) FK 0.9 kg/tree/year, 4) FK 1.2 kg/tree/year, 5) FK $1.5 \mathrm{~kg} /$ tree/year, and 6) FK $1.8 \mathrm{~kg} /$ tree/year, whereas those for mature crops were similar but different dosages, i.e., 1) kieserite $2.0 \mathrm{~kg} /$ tree/year, 2) FK 1.0 kg/tree/year, 3) FK 1.5 kg/tree/year, 4) FK 2.0 kg/tree/year, 5) FK 2.5 kg/tree/year, and 6) FK $3.0 \mathrm{~kg} /$ tree/year. Vegetative and generative observations were made for one year after treatments and the data were subjected to statistical analyses. The vegetative parameters were number of fronds and number, length, and width of petioles, whereas the generative ones were number, weight, and average weight of fresh fruit bunches (FFB).

\section{Results and Discussion}

\subsection{Properties of Sidayu Dolomite}

Dolomite ores in Indonesia are found in several locations spreading from Aceh in the North up to East Java in the East. Among dolomite sites, the highest deposits and quality is the one in Sidayu, Gresik, East Java. Its quality for agricultural use has been set by the Industrial National Standard (SNI) \# 02-2804-2005 especially for Mg fertilizer (Table 1). Compared with chemical characteristics of kieserite, this dolomite consists less $\mathrm{MgO}$, both for total and water-soluble one, dominated by $\mathrm{Ca}$, less soluble, and alkaline in reaction. According to the SNI, a kieserite as $\mathrm{Mg}$ fertilizer must contain $27 \%$ - 29\% $\mathrm{MgO}(17.56 \% \mathrm{Mg})$, whereas in dolomite from Sidayu the $\mathrm{MgO}$ was only $18 \%-22 \%$ (13.18\% Mg). Therefore, the process intended to process dolomite to meet kieserite standard is to reduce $\mathrm{CaO}$ and/or $\mathrm{CO}_{2}$ resulting ini the increase of relative composition of the $\mathrm{MgO}$.

Due to its lower $\mathrm{MgO}$ contents compared to kieserite, therefore some additional process was performed. Several studies have indicated that calcination will improve the $\mathrm{MgO}$ content of dolomite while in the same time reduce the $\mathrm{CaO}$ 
content [Pustaka]. Our data in Table 2 show that after calcination at $600^{\circ} \mathrm{C}$ for one hour, the characteristics of dolomite were improved approaching those of kieserite, especially in those of total and water-soluble $\mathrm{MgO}$.

\subsection{Mineralogical Characteristics}

Data shown in Figure 1 indicate the present of several minerals based on XRD analysis both in non-calcined and calcined dolomites. The present of dolomite mineral $\left(\mathrm{CaMg}\left(\mathrm{CO}_{3}\right)_{2}\right)$ in both samples are shown by the peak with 2 theta symbol of $2.86 \AA$. Original dolomite was dominated by dolomite $(99.8 \%)$ and only $0.2 \%$ cristobalite $\left(\mathrm{SiO}_{2}\right)$ present (Table 3$)$. The latter is shown by a $2.33 \AA$ peak at $30^{\circ} 2$-theta. In calcined dolomite, a layer is formed that covers the surface pores of the original dolomite, resulting in the inhibition of $\mathrm{CO}_{2}$ gas product from exiting the interface reaction. It is expected that there will be an increase in the levels of $\mathrm{CaO}$ and $\mathrm{MgO}$ when compared to the non-calcined dolomite (Figure 1). Calcined dolomite is dominated by calcite $\left(\mathrm{CaCO}_{3}\right)$ about $80.2 \%$ with $19.4 \%$ of an $\mathrm{MgO}$ mineral periclase and a few dolomite (0.4\%) (Table 3). These data confirmed that thermal treatment promotes decomposition of $\mathrm{CaMg}\left(\mathrm{CO}_{3}\right)_{2}$ at certain temperature [28] [29]. It has been reported by others [30] that decomposition of this carbonate mineral will first release magnesium and later at a higher temperature followed by calcium. As reported by [31] the conversion reaction is most likely following this path:

$$
\mathrm{CaMgCO}_{3}+\mathrm{O}_{2} \rightarrow \mathrm{CaCO}_{3}+\mathrm{MgO}+\mathrm{CaMg}\left(\mathrm{CO}_{3}\right)_{2}
$$

Table 1. Physico-chemical characteristics of standar Kieserite and the Sidayu dolomite.

\begin{tabular}{ccc}
\hline Characteristics & Kieserite & Dolomite \\
\hline Total $\mathrm{MgO}(\%)$ & $27-29$ & $18-22$ \\
$\mathrm{MgO}(\%)$ & 17.56 & 13.18 \\
Other Nutrient (\%) & $\mathrm{S}=22$ & $\mathrm{CaO}=30$ \\
Water solubility & Fairly & Hardly \\
Reaction & Slightly acid & Alkaline \\
\hline
\end{tabular}

Table 2. Effect of calcination on dolomite characteristics.

\begin{tabular}{ccc}
\hline Characteristics & Untreated Dolomite & Calcined Dolomite \\
\hline Total $\mathrm{MgO}(\%)$ & 16.10 & 26.70 \\
Water soluble $\mathrm{MgO}(\%)$ & 4.50 & 9.20 \\
$\mathrm{CaO}(\%)$ & 29.10 & 30.04 \\
$\mathrm{Al}_{2} \mathrm{O}_{3}(\%)$ & 0.02 & 0.03 \\
$\mathrm{Fe}_{2} \mathrm{O}_{3}(\%)$ & 0.27 & 0.25 \\
$\mathrm{SiO}_{2}(\%)$ & 0.03 & 0.02 \\
$\mathrm{pH}$ & 8.5 & 9.10 \\
Neutralizing capacity (\%) & 106.2 & 100.10 \\
Water Content (\%) & 1.15 & 1.02 \\
\hline
\end{tabular}


Table 3. Quantitative analysis of minerals presence in non- and calcined dolomite by using XRD.

\begin{tabular}{ccc}
\hline Sample & Mineral Species & Amounts (\%) \\
\hline \multirow{2}{*}{ Non-calcined } & Dolomite & 99.8 \\
& Cristobalite & 0.2 \\
\hline \multirow{2}{*}{ Calcined } & Calcite & 80.2 \\
& Periclase & 19.4 \\
& Dolomite & 0.4 \\
\hline
\end{tabular}

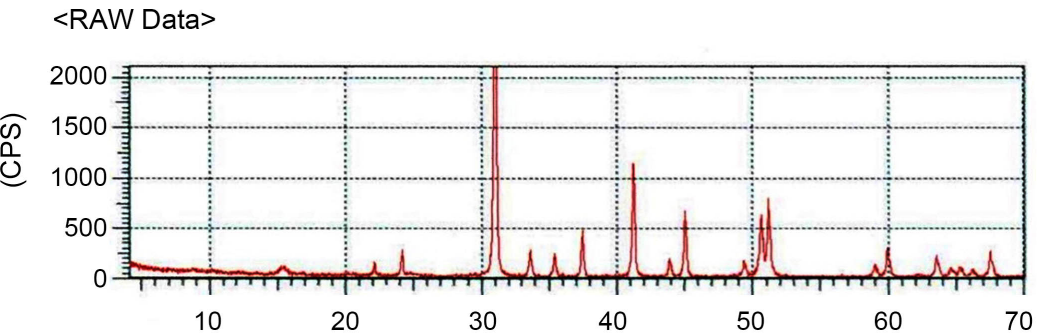

(a)

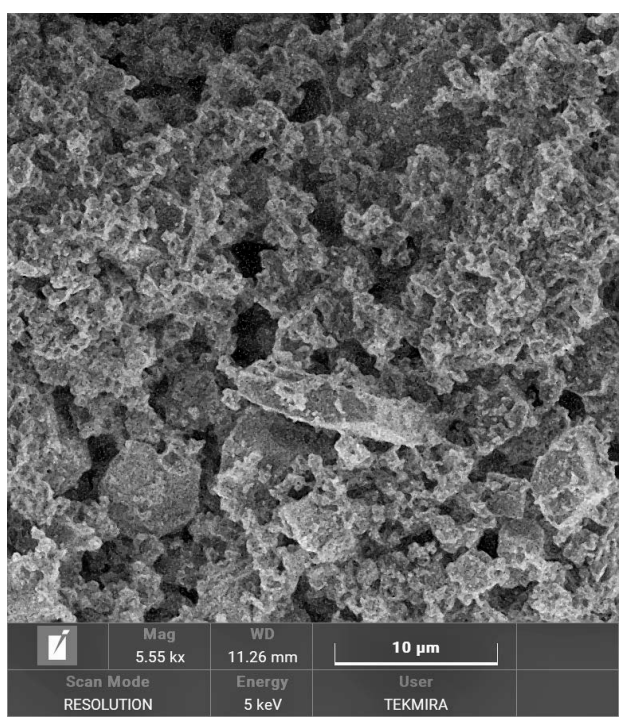

(b)

Figure 1. X-Ray Diffractogram: non-calcined (upper) and calcined (bottom) (A) and Scanning Electron Microscopes: non calcined (left) and calcined (right) dolomites (B), indicating decomposition of the mineral after $800{ }^{\circ} \mathrm{C}$ heating for one hour.

The data in Table 3 also show that cristobalite $\left(\mathrm{SiO}_{2}\right)$ was totally decomposed at $800^{\circ} \mathrm{C}$ temperature as reported by [29]. The evidences of calcite $\left(\mathrm{CaCO}_{3}\right)$ and periclase $(\mathrm{MgO})$ minerals in Figure 1(a) are shown by the peaks at 2.71 and 3.59 $\AA$, respectively. These evidences were not conclusively supported by SEM images which indicate that calcination at $800^{\circ} \mathrm{C}$ decomposes dolomite mineral into a smaller particle. However, the SEM images of dolomite obtained in this study are similar to those reported by [32]. 


\subsection{Effect of Formulated Kieserite on Oil Palm}

Results on greenhouse experiment indicated that the newly formulated kieserite fertilizer could replace conventional kieserite (Table 4). The replacement of Mgfertilizer from kieserite to $\mathrm{FK}$ at reduced dosage $(75 \%)$ produced seedlings with dry weights of leaves, stems, and roots similar to those of conventional kieserite. Vegetative growth improvement obtained was presumably due to the present of $\mathrm{Ca}$ in the FK compared to none in the conventional kieserite. Other implication of this result is that the cost of fertilization by using FK would be less than conventional kieserite assuming that the price of the former is less than the later.

Data shown in Figure 2 and Figure 3 indicate the effect of new formulated $\mathrm{Mg}$ fertilizer on the growth of a three-year-old immature oil palm represented by length and number of fronds, respectively, in comparison with the standard application of $\mathrm{Mg}$ fertilizer (i.e., kieserite). It is indicative that the use of $0.9 \mathrm{~kg}$ FK was producing significantly longer fronds and similar number of fronds compared to that of control treatment (1.2 Kg Kieserite/tree). This means that the newly formulated $\mathrm{Mg}$ fertilizer can reduce the dosage up to $25 \%$ compared to kieserite dosage. Figure 4 and Figure 5 present the effect of FK dosage on the yield components of mature oil palm, i.e., on the fresh fruit bunches (FFB) number and average weight of FFB, respectively. The application of newly formulated kieserite at $1.0 \mathrm{~kg} /$ tree rate provided similar to or higher than the conventional kieserite applied at $2.0 \mathrm{~kg} /$ tree. A fifty percent reduction on fertilizer rate without significant effect on the crop performances especially yield will in turn provide a better economic value to the farmers.

Table 4. Dry weight average of six-month old oil palm seedlings grown on an acid soil under greenhouse condition affected by various dosages of newly formulated kieserite (FK).

\begin{tabular}{ccccc}
\hline \multirow{2}{*}{ No } & Treatments & \multicolumn{3}{c}{ Dry Weight of (g) } \\
\cline { 3 - 5 } & & Leave & Stem & Roots \\
\hline 1 & $100 \%$ dosage of NPKMg-kieserite & $18.5 \mathrm{a}^{*}$ & $17.8 \mathrm{a}$ & $5.6 \mathrm{abc}$ \\
2 & $100 \%$ dosage of NPK + 25\% FK & $15.6 \mathrm{bc}$ & $15.5 \mathrm{ab}$ & $5.2 \mathrm{bcd}$ \\
3 & $100 \%$ dosage of NPK + 50\% FK & $14.3 \mathrm{~cd}$ & $12.8 \mathrm{~b}$ & $3.9 \mathrm{~d}$ \\
4 & $100 \%$ dosage of NPK + 75\% FK & $19.8 \mathrm{a}$ & $18.1 \mathrm{a}$ & $6.9 \mathrm{a}$ \\
5 & $100 \%$ dosage of NPK + 100\% FK $\left.{ }^{* *}\right)$ & $13.9 \mathrm{~cd}$ & $13.1 \mathrm{~b}$ & $4.6 \mathrm{~cd}$ \\
6 & $100 \%$ dosage of NPK + 125\% & $17.7 \mathrm{ab}$ & $17.9 \mathrm{a}$ & $5.9 \mathrm{ab}$ \\
7 & $100 \%$ dosage of NPK + 150\% FK & $15.9 \mathrm{bc}$ & $15.2 \mathrm{ab}$ & $4.8 \mathrm{bcd}$ \\
8 & $100 \%$ dosage of NPKMg-dolomite & $15.4 \mathrm{bc}$ & $15.2 \mathrm{ab}$ & $4.9 \mathrm{bcd}$ \\
& & 8.3 & 10.7 & 13.1 \\
\hline
\end{tabular}

\footnotetext{
*) Figures in the same column followed by the letter(a) were not significantly different according to Duncan Multiple Ranget Test $\left.(\mathrm{P}<0.05) .{ }^{* *}\right) 100 \%$ dosage of Mg-FK equals to optimum dosage of Mg-Kieserite, i.e., 0.8 gram/seedling (Kasno \& Nurjaya, 2011).
} 


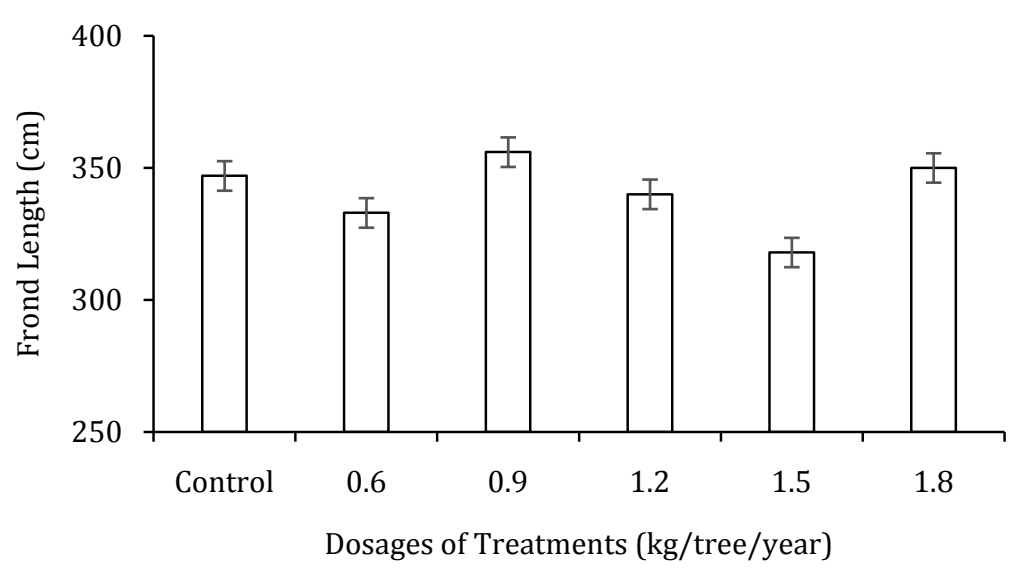

Figure 2. Effect of newly-formulated Mg fertilizer on the frond length of a three years old immature oil palm in comparison with conventional kieserite (Control, $1.2 \mathrm{Kg}$ kieserite/tree/year).

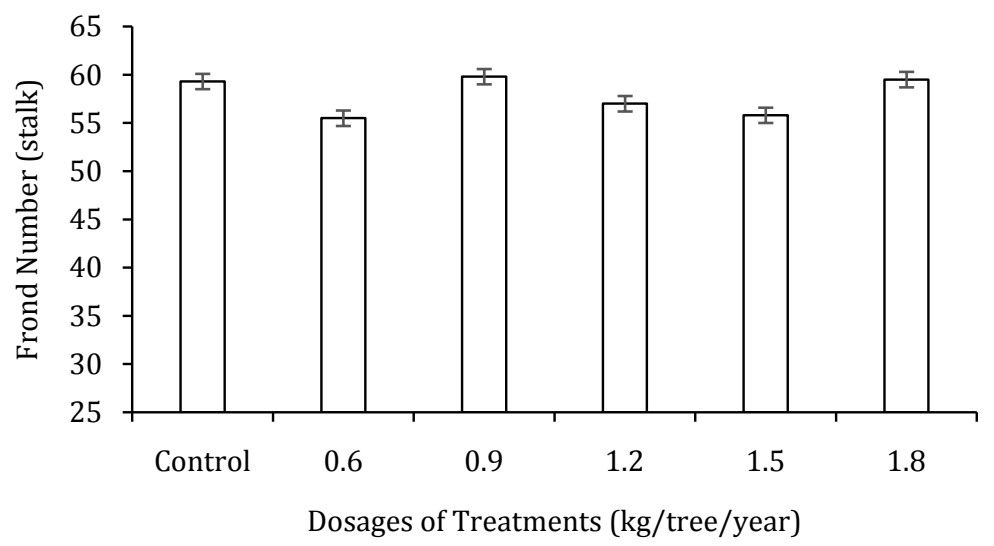

Figure 3. Effect of newly-formulated $\mathrm{Mg}$ fertilizer on the frond number of a three years old immature oil palm in comparison with conventional kieserite (Control, $1.2 \mathrm{~kg}$ kieserite/tree/year).

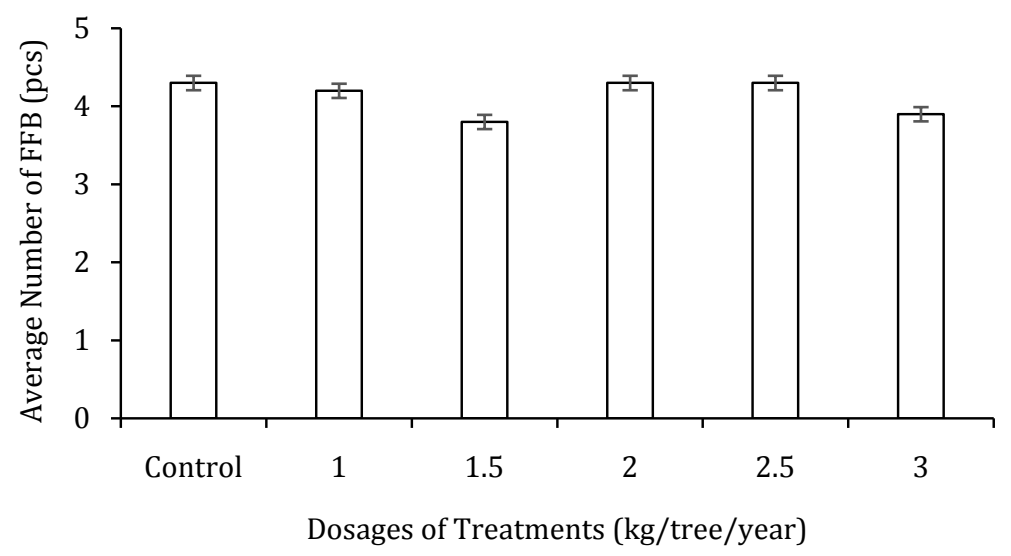

Figure 4. Effect of newly-formulated $\mathrm{Mg}$ fertilizer on the FFB number of a five years old mature oil palm in comparison with conventional kieserite (Control, i.e., $2 \mathrm{~kg} /$ tree/year). 


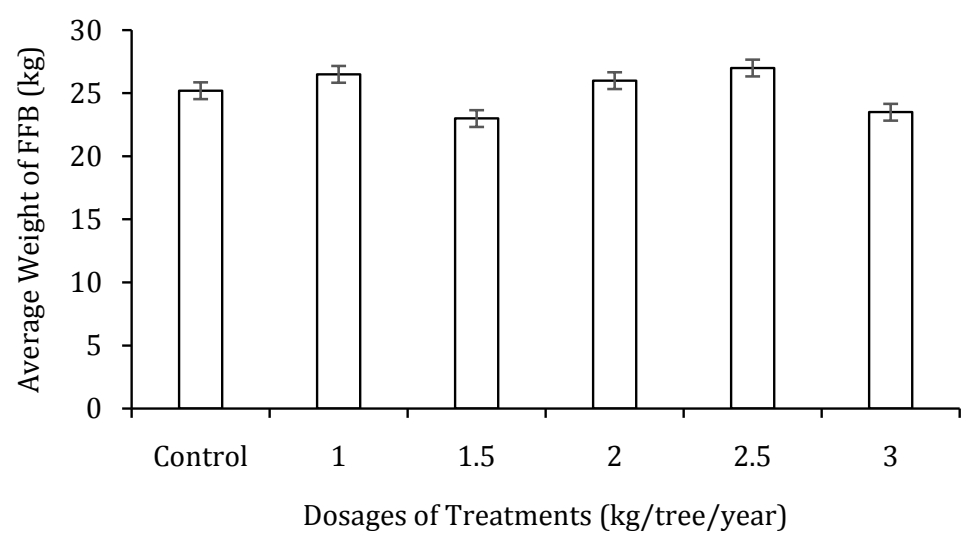

Figure 5. Effect of newly-formulated $\mathrm{Mg}$ fertilizer on the FFB average weight of a five years old mature oil palm in comparison with conventional kieserite (Control, i.e., $2 \mathrm{~kg} /$ tree/year).

Based on the above findings, the reduction of $\mathrm{Mg}$ fertilizer up to $50 \%$ compared to that of kieserite under current prices of fertilizers locally yields a cost efficiency of fertilization up to $14.4 \%$. Under current prices condition in which crude palm oil reaching high price level ever and the significant increase in price of all fertilizers, this newly formulated $\mathrm{Mg}$ fertilizer will in turn provide a better profit margin to the farmers.

\section{Conclusion}

To relieve the pressure on profitability of oil palm farmers in oil palm producing countries due to fertilizer price hikes, this technology has shown a highly prospective as alternative for a new $\mathrm{Mg}$ fertilizer replacing conventional kieserite. By applying bio-phisico-chemical treatment on a Sidayu dolomite, an alternative kieserite was developed with a superior performance compared to that on conventional kieserite for oil pam both in nursery and in the field (immature and mature trees).

\section{Acknowledgements}

The authors wish to thank PT Polowijo Gosari Group for their valuable supports and provision of experiment materials.

\section{Conflicts of Interest}

The authors declare no conflicts of interest regarding the publication of this paper.

\section{References}

[1] Finch, H.J.S., Samuel, A.M. and Lane, G.P.F. (2014) Lockhart and Wiseman Crop Husbandry including Grassland. 9th Edition, Elsevier Ltd., London. https://doi.org/10.1533/9781782423928.2.245

[2] Van-Straaten, P. (2007) Agrogeology: The Use of Rocks for Crops. Department of 
Land Resource Science, University of Guelph, Guelph, 440 p.

[3] Perera, Y. (2016) Fertilizer Grade Magnesium Sulphate Production from Dolomite. Department of Chemical and Process Engineering, University of Moratuwa, Moratuwa. https://www.researchgate.net/publication/335611914

[4] Serrano, J., Shahidian, S., da Silva, J.M., Moral, F., Carvajal-Ramirez, F., Carreira, E., Pereira, A. and de Carvalh, M. (2020) Evaluation of the Effect of Dolomitic Lime Application on Pastures-Case Study in the Montado Mediterranean Ecosystem. Sustainability, 12, Article No. 3758. https://doi.org/10.3390/su12093758

[5] Sidhu, M., Hasyim, A., Rambe, E.F., Sinuraya, Z., Aziz, A. and Sharma, M. (2014) Evaluation of Various Sources of Magnesium Fertilizer for Correction of Acute Magnesium Deficiency in Oil Palm. Oil Palm Bulletin, 69, 27-37.

[6] Sanputawong, S., Chansathean, K., Peakchantuk, N. and Chuiruy, C. (2017) Study of Proper Fertilizer Management on Growth and Yield of Oil Palm (Eleais guineensis Jacq.). International Journal of Agricultural Technology, 13, 2631-2639.

[7] Ayanda, A.F., Jusop, S., Ishak, C.F. and Othman, R. (2020) Utilization of Magnesium-Rich Synthetic Gypsum as Magnesium Fertilizer for Oil Palm Grown on Acidic Soil. PLoS ONE, 15, e0234045. https://doi.org/10.1371/journal.pone.0234045

[8] Gonidanga, B.S., Njoya, D., Lecomte-Nana, G. and Njopwouo, D. (2019) Phase Transformation, Technological Properties and Microstructure of Fired Products Based on Clay-Dolomite Mixtures. Journal of Materials Science and Chemical Engineering, 7, 1-14. https://doi.org/10.4236/msce.2019.711001

[9] Anjiang, S., Jianfeng, Z., Yongquan, C., Xinfeng, N. and Lili, H. (2016) Characteristics, Origin and Distribution of Dolomite Reservoirs in Lower-Middle Cambrian, Tarim Basin, NW China. Petroleum Exploration and Development, 43, 375-385. https://doi.org/10.1016/S1876-3804(16)30044-1

[10] Zhang, J.Y., Ni, X.F., Wu, X.N., Li, W.Z., Hao, Y., Chen, Y.N., Lü, X.J., Gu, M.F., Tian, H. and Zhu, M. (2018) Main Controlling Factors and Distribution of HighQuality Deep Dolomite Reservoirs in Typical Cratonic Basins in China. Journal of Natural Gas Geoscience, 3, 81-93. https://doi.org/10.1016/j.jnggs.2018.04.003

[11] Bray, E.L. (2020) Mineral Commodity Summaries 2020. US Geol. Survey, 200 p.

[12] Tompa, E., Nyiro-Kosa, I., Rosfasi, A., Cserny, T. and Posfai, M. (2012) Distribution and Composition of Mg-Calcite and Dolomite in the Water and Sediment of Lake Balaton. Central European Geology, 57, 113-136.

https://doi.org/10.1556/CEuGeol.57.2014.2.1

[13] Florida Department of Environmental Protection (2021) Limestone, Shell, Dolomite.

https://floridadep.gov/water/mining-mitigation/content/limestone-shell-dolomite

[14] Solihin (2018) The Review of Recent Carbonate Minerals Processing Technology. IOP Conference Series. Earth and Environmental Science, 118, Article ID: 012065. https://doi.org/10.1088/1755-1315/118/1/012065

[15] Yang, Y.G., He, Z.L., Yang, X.E., Fan, J.H., Stoffela, P. and Brittain, C. (2012) Dolomite Phosphate Rock-Based Slow Release Fertilizer for Agriculture and Landscapes. Communications in Soil Science and Plant Analysis, 43, 1344-1362. https://doi.org/10.1080/00103624.2012.666308

[16] Shreckhise, J.H., Owen, J.S., Eick, M.J., Niemiera, A.X., Altland, J.E. and Jackson, B.E. (2020) Dolomite and Micronutrient Fertilizer Affect Phosphorus Fate When Growing Crape Myrtle in Pine Bark. American Society for Horticultural Science, 55, 832-840. https://doi.org/10.21273/HORTSCI14558-20 
[17] Demosthenous, M. (2012) Magnesium Sulphate. Patent WO2013037649A1. http://www.google.com/patents/WO2013037649A1?cl=zh

[18] Wahyudi, T. and Damayanti, R. (2013) Effect of Reagent Volume and Concentration on Recoveries of $\mathrm{MgO}$ and $\mathrm{SO}_{3}$ within Synthetic Dolomite-Based Kieserite. Indonesian Mining Journal, 16, 162-172. https://doi.org/10.30556/imj.Vol16.No3.2013.384

[19] Sulistiyono, E., Firdiyono, F., Natasha, N.C. and Amalia, Y. (2017) Comparison of Dolomite Crystal Structure, Calcinations Dolomite, and Magnesium Hydroxide in Partial Calcinations and Slaking Process. IOP Conference Series. Materials Science and Engineering, 176, Article ID: 012041. https://doi.org/10.1088/1757-899X/176/1/012041

[20] Santi, L.P. and Goenadi, D.H. (2017) Solubilization of Silicate from Quartz Mineral by Potential Silicate-Solubilizing Bacteria. E-Journal Menara Perkebunan, 85, 96-104. https://doi.org/10.22302/iribb.jur.mp.v85i2.247

[21] Kalbuadi, D.N., Santi, L.P., Goenadi, D.H. and Barus, Y. (2020) Application of Biosilicic Acid to Improve Yield and Fertilizer Efficiency of Paddy on Tidal Swamp Land. E-Journal Menara Perkebunan, 88, 111-119. https://doi.org/10.22302/iribb.jur.mp.v88i2.378

[22] Santi, L.P., Ardiyanto, A., Kurniawan, A., Prabowo, L. and Sebastian, I. (2021) Improvement of Water and Nutrient Efficiencies of Oil Palm through Bio-Silicic Acid Application. E-Journal Menara Perkebunan, 89, 26-36.

https://doi.org/10.22302/iribb.jur.mp.v89i1.409

[23] Santi, L.P. and Goenadi, D.H. (2012) The Potential Use of Bio-Activated Potassium-Bearing Mineral from East Java for K Fertilizer. E-Journal Menara Perkebunan, 80, 1-7. https://doi.org/10.22302/iribb.jur.mp.v80i2.33

[24] Goenadi, D.H. and Santi, L.P. (2012) Bio-Superphosphate (Bio-SP) Application on Sugarcane (Saccharum officinarum L.). AGRIVITA: Journal of Agricultiral Science, 35, 8-12. https://doi.org/10.17503/Agrivita-2013-35-1-p008-012

[25] Beruto, D.T., Vecchiattini, R. and Giordani, M. (2003) Solid Products and RateLimiting Step in the Thermal Half Decomposition of Natural Dolomite in a $\mathrm{CO}_{2}(\mathrm{~g})$ Atmosphere. Thermochimica Acta, 405, 183-194. https://doi.org/10.1016/S0040-6031(03)00190-4

[26] Jambulingam, M., Karthikeyan, S., Sivakumar, P., Kiruthika, J. and Maiyalagan, T. (2007) Characteristic Studies of Some Activated Carbons from Agricultural Wastes. Journal of Scientific and Industrial Research, 66, 495-500.

[27] Cullity, B.D. and Stock, S.R. (2001) Elements of X-Ray Diffraction. Prentice Hall, Upper Saddle River, NJ.

[28] Olszak-Huminiek, M. and Jablonski, M. (2014) Thermal Behavior of Natural Dolomite. Journal of Thermal Analysis and Calorimetry, 119, 2239-2248. https://doi.org/10.1007/s10973-014-4301-6

[29] Wulandari, W., Subagjo Mursito, A.T., Junjaya, F.J. and Alwi, M.J. (2018) Performance of Dolomite Calcination in a Bench-Scale Rotary Kiln. MATEC Web of Conferences, 156.

[30] Gunasekaran, G. and Anbalagan, G. (2007) Thermal Decomposition on Natural Dolomite. Bulletin of Materials Science, 30, 339-344. https://doi.org/10.1007/s12034-007-0056-Z

[31] Abdullah, S.F.A., Saleh, S.S.M., Mohammad, N.F., Idris, M.S. and Saliu, H.R. (2021) Effect of Thermal Treatment on Natural Dolomite. Journal of Physics. Conference Series, 2080, Article ID: 012009. https://doi.org/10.1088/1742-6596/2080/1/012009 
[32] Gruszecka-Kosowska, A., Baran, P., Wdowin, M. and Franus, W. (2017) Waste Dolomite Powder as an Adsorbent of $\mathrm{Cd}, \mathrm{Pb}$ (II), and $\mathrm{Zn}$ from Aqueous Solutions. Environmental Earth Sciences, 76, Article No. 521.

https://doi.org/10.1007/s12665-017-6854-8 